\title{
P01-014 - Subclinical atherosclerosis in FMF
}

\author{
S Ugurlu', SN Karaca ${ }^{2}$, Y Demirel ${ }^{2}$, E Seyahi $^{i^{*}}$ \\ From 7th Congress of International Society of Systemic Auto-Inflammatory Diseases (ISSAID) \\ Lausanne, Switerland. 22-26 May 2013
}

\section{Introduction}

Whether atherosclerosis is increased or not in Familial Mediterranean Fever (FMF) is a much debated issue. Carotid artery intima media thickness (IMT) a surrogate marker for subclinical atherosclerosis is found to be increased in a number of studies [1-5], however this contrasts with the lack of increased frequency of atherosclerotic plaques[1-5]. Also, population surveys do not indicate an increased prevalence of ischaemic heart disease in FMF patients. In the current study, we hypothesized that FMF patients with no apparent atherosclerotic risk factor would have no increase in the carotid artery IMT.

\section{Objectives}

To investigate markers of carotid atherosclerosis and oxidized low density lipoprotein (oxLDL) levels in patients with FMF who have no risk factors for cardiovascular disease.

\section{Methods}

We studied 44 patients (25 F/19 M; mean age: $33.5 \pm 7.5$ ) with FMF in attack free period and gender and age matched 44 healthy subjects (25 F/19 M; mean age: 33.4 \pm 7.0 ). Exclusion criteria were clinical coronary artery disease, chronic renal disease, diabetes mellitus, hypertension, history of myocardial infarction, angina pectoris or cerebrovascular disease, dyslipidemia, metabolic syndrome or active infection. Those who were in postmenopausal status and using antilipid drugs were also excluded. We measured carotid artery IMT and investigated presence or absence of atherosclerotic plaques in the carotids, using Doppler ultrasound. We also assessed serum lipid and OxLDL levels.

\section{Results}

Mean disease duration of the FMF patients was $20 \pm 9$ years. The mean carotid IMT (C-IMT) did not differ between patients and controls $(0.52 \pm 0.10 \mathrm{~mm}$ vs 0.53 $\pm 0.06 \mathrm{~mm}$, respectively, $\mathrm{P}=0.709$ ). None of the patients or controls had atherosclerotic plaques. Total and LDL cholesterol levels were significantly lower among patients compared to controls (total cholesterol: 157.07 \pm 34.18 vs $181.05 \pm 36.79$, respectively, $\mathrm{P}=0.002$; LDL cholesterol: $100.48 \pm 30.13$ vs $126.25 \pm 34.05$, respectively, $\mathrm{P}=0.001)$. Whereas OxLDL levels were significantly higher in FMF patients $(337.48 \pm 438.56 \mathrm{ng} / \mathrm{dl})$ when compared to controls $(156.19 \pm 383.24 \mathrm{ng} / \mathrm{dl}),(\mathrm{P}=0.044)$. There was no correlation between CIMT and OxLDL levels among both patients $(\mathrm{r}=-0.156, \mathrm{p}=0.324)$ and controls $(\mathrm{r}=-0.196, \mathrm{p}=0.246)$.

\section{Conclusion}

Our study supports further evidence for no increased atherosclerosis in FMF. As previously shown patients with FMF have low cholesterol levels when compared to healthy controls $[1,2]$. On the other hand, increased OxLDL levels could be associated with increased subclinic inflammation.

\section{Disclosure of interest}

None declared.

\begin{abstract}
Authors' details
'Department of Internal Medicine, Division of Rheumatology, Cerrahpasa Medical Faculty, University of Istanbul, Istanbul, Turkey. ${ }^{2}$ Department of Family Mediciney, Medical Faculty, University of Cumhuriyet, Sivas, Turkey, Sivas, Turkey.
\end{abstract}

Published: 8 November 2013 


\section{References}

1. Ugurlu S, Seyahi E, Cetinkaya F, et al: Rheumatology (Oxford) 2009, 48:911-5.

2. Akdogan A, Calguneri M, Yavuz B, et al: J Am Coll Cardiol 2006, 48:2351-3.

3. Peru H, Altun B, Doğan M, et al: Clin Rheumatol 2008, 27:689-94.

4. Sari I, Karaoglu O, Can G, et al: Clin Rheumatol 2007, 26:1467-73.

5. Bilginer Y, Ozaltin F, Basaran C, et al: Rheumatol Int 2008, 28:1211-16.

doi:10.1186/1546-0096-11-S1-A18

Cite this article as: Ugurlu et al:: P01-014 - Subclinical atherosclerosis in FMF. Pediatric Rheumatology 2013 11(Suppl 1):A18.

Submit your next manuscript to BioMed Central and take full advantage of:

- Convenient online submission

- Thorough peer review

- No space constraints or color figure charges

- Immediate publication on acceptance

- Inclusion in PubMed, CAS, Scopus and Google Scholar

- Research which is freely available for redistribution 